\title{
Koncepti izravne primjene $i$ izravnog učinka u pravu Europske unije
}

\section{Koraljka Sansovic ${ }^{*}$}

\author{
http://doi.org/10.31297/hkju.20.2.1 \\ UDK 341.24:061.1(4)EU \\ 341.176(4)EU:341.24 \\ 341.645(4)EU:341.98 \\ Original scientific paper / izvorni znanstveni rad \\ Received/primljeno: 31.10.2019. \\ Accepted/prihvaćeno: 28. 2. 2020.
}

U radu se analiziraju koncepti izravne primjene i izravnog učinka koji su se razvili u praktičnoj primjeni uredaba i direktiva kao obvezujućih akata sekundarnoga europskog zakonodavstva. Autorica dokazuje da se direktivama u određenim slučajevima priznaje izravni učinak, a uredbama odriče; da je kod direktiva izravna primjena u pravilu posljedica izravnog učinka, a kod uredaba izravni učinak posljedica izravne primjene; da su u nekim slučajevima i u vezi s nekim vrstama akata ti koncepti katkad uzajamno uvjetovani, a katkad ne, tvrdeći da su te iznimke od pravila posljedica zahtjeva za učinkovitošću europskog prava na nacionalnoj razini te primjene prava po metodi case by case. Autorica, međutim, smatra da ti zahtjevi i metode ne dovode u pitanje originalna temeljna pravna pravila, da oni

* Dr. sc. Koraljka Sansović, Ministarstvo vanjskih i europskih poslova, Zagreb, Hrvatska (Ministry of Foreign and European Affairs, Zagreb, Croatia, e-mail: koraljka. sansovic@mvep.hr). Mišljenja i stavovi izraženi u radu autoričina su osobna mišljenja i nisu stav institucije u kojoj radi.

ORCID ID: https://orcid.org/0000-0002-6250-1746 
označavaju odstupanje, ali ne i ukidanje temeljnih pisanih pravila te su potrebni radi razvoja europskog prava i postizanja njegovih ciljeva koji bi mogli doći u pitanje ako bi se primjenjivao strogi formalizam.

Ključne riječi: izravna primjena, izravni učinak, uredba, direktiva, europsko pravo

\section{Uvod}

$\mathrm{Na}$ temelju primarnog zakonodavstva u kojem su sadržane definicije uredaba i direktiva stvoreni su koncepti, odnosno termini »izravna primjena « i »izravni učinak«. Vežu se uz navedene vrste akata, ali se poslije upotrebljavaju uopćeno. Osnovna ideja u definiranju tih vrsta akata u članku 288. Ugovora o funkcioniranju Europske unije (bivši čl. 249. UEZ-a, odnosno 189. UEEZ-a) ${ }^{1}$ bila je naglasiti da su obje vrste akata obvezujući dokumenti te da se želi zadržati veća koherentnost i jedinstvenost primjene uredaba, pa se ne traži dodatni angažman država članica i njihovih tijela, već ih one trebaju bez posredovanja primjenjivati (st. 2. navedenog članka), dok se kod direktiva ipak, uzimajući u obzir različitosti uvjeta u državama članicama, ostavlja prostor državama članicama da postignu zadane ciljeve, uz slobodu da to učine na način koji same odaberu (st. 3. navedenog članka). To je osnovna ideja koja možda u teoriji zvuči jednostavno i logično, a u praksi nailazi, kao i svako pravilo, na određene poteškoće. Teško je i nepreporučljivo uvijek i svugdje bez iznimke očekivati takvu primjenu. To je uvidio Sud Europske unije (dalje u tekstu: Europski sud) u svojoj dugogodišnjoj praksi te je kod direktiva odredio i druge načine i pravila ako prvo pravilo nije moguće bezrezervno primijeniti. $U$ biti su razvoj odnosa, pa posljedično i razvoj prava, ali i zahtjev za humano postizanje ciljeva europskog prava zahtijevali i zahtijevaju određena odstupanja od prvotnih definicija. Što se tiče uredaba, sam je zakonodavac uvidio slične probleme, pa se i kod njih uviđaju sve češće regulatorno propisane iznimke od temeljnog pravila.

Svrha je ovog rada analizirati koncept izravne primjene i izravnog učinka u odnosu na uredbe i direktive kako bi se istodobno upozorilo na odre-

1 Pročišćena verzija Ugovora o funkcioniranju Europske unije, Ugovor o Europskoj uniji, SL C 202, 7. 6. 2016., str. 1-388. 
đena legitimna odstupanja od originalnih zakonodavnih definicija i na to da, ako se u početku stvaranja europskog prava možda i moglo tolerirati miješanje tih njihovih značenjskih oznaka - termina, danas je razvojem prava došlo do određena sadržajnog razlikovanja te je zaista potrebno ne samo njihovo razlikovanje nego i supostojanje. Stoga će se analizirati priznavanje izravnog učinka direktivama, koje ga načelno ne bi trebale imati prema odredbi primarnog zakonodavstva, čl. 288. Ugovora o funkcioniranju Europske unije, i izravna primjena u odnosu na tu situaciju te relacije tih koncepata kod uredaba. U zasebnom će se naslovu radi razjašnjavanja obraditi njihova povezanost u slučaju sudjelovanja obiju vrsta akata u reguliranju određene materije, ali i razlike koje bez obzira na kompleksnost primjene i dalje postoje i potrebne su. U radu se želi naglasiti karakteristika ili težnja europskog prava: da ono nije podložno striktno formalnim pravilima, u čemu se uvelike razlikuje od shvaćanja i interpretacije prava na nacionalnoj razini te da se od svakog pravila odstupa radi učinkovite i humane primjene europskih odredaba, da derogiranje temeljnih pravila ne znači automatski njihovo ukidanje, već odgovor na društvena kretanja i prilagodbu te razvoj prava. Na kraju rada bit će prikazan recentan praktični zakonodavni slučaj koji otvara određena pitanja vezana uz temu.

\section{Označavaju li termini »izravna primjena« $\mathrm{i}$ »izravni učinak« isti pravni koncept?}

Koncepti izravne primjene i izravnog učinka u praksi i teoriji vrlo su se često rabili kao sinonimi, pa se i danas neki iznimno ugledni teoretičari (Craig \& de Burca, 2015, str. 277-300 i dalje) koriste tim dvama terminima kao sinonimima, upotrebljavajući izravnu primjenu kao atributnu jezičnu varijaciju za akt koji ima izravni učinak. Razlog je tomu što ni u zakonodavstvu ni u presudama Suda ne postoji pisana i precizna njihova definicija. Postavlja se pitanje je li zaista riječ o sinonimima. Pogledat ćemo ukratko neke situacije iz razvoja europskog prava i pokušati utvrditi što bi mogle biti definicije tih pojmova i postoje li razlike. Vidjet ćemo da se ti pojmovi tijekom razvoja prava miješaju, katkad se koriste kao sinonimi, katkad se prave određene razlike, ali samo u odnosu na pojedinu i konkretnu vrstu akata, najčešće u odnosu na uredbe i direktive. S obzirom na noviji razvoj prava gdje supostoje i upotrebljavaju se oba pojma, postavlja se pitanje pretpostavlja li izravni učinak u svakom slučaju izravnu primjenu. Je li moguće da se neka odredba izravno primjenjuje, a da nema 
izravni učinak i obratno? Na ta pitanja ovaj će rad nastojati dati odgovore. Zbunjujuć je i tekst koji se nalazi na pravnim portalima gdje se navodi, doduše, da se ti pojmovi često ne koriste kao istoznačnice, ali uvodi zbrku u razumijevanje samih koncepata, a posljedično i primjenu odredaba uredaba i direktiva. Tekst glasi: »Iako se često miješa s doktrinom izravnog učinka, izravna primjena odnosi se na činjenicu da uredbe ne zahtijevaju provedbeno zakonodavstvo, one proizvode pravne učinke od dana objave. Ta se zbrka možda može objasniti pozivanjem na odredbe Ugovora o uredbama kojima se određuje da samo one imaju izravni učinak u državama članicama. Rana praksa Suda sugerira da je izravni učinak posljedica izravne primjene, kao što je bilo i u nacrtima originalnih Ugovora predviđeno da samo uredbe imaju izravni učinak. Međutim, širenje doktrine izravnog učinka na direktive i druge mjere dovelo je do razlikovanja izravnog učinka i izravne primjene. $\ll^{2}$ Prema tom je tekstu izravni učinak u slučaju uredaba neizbježna i konstantna posljedica izravne primjene, čak se do te mjere miješa da se tumači da ga tekst odredbe primarnog zakonodavstva daje uredbama. S obzirom na to da se koncepti očigledno zamjenjuju zbog nepostojanja definicije, pokušat ćemo ih analizirati u konkretnim primjerima i slučajevima.

Usprkos sadržajnom poistovjećivanju tih termina možemo utvrditi da ih Sud već u svojim ranim presudama razlikuje. U predmetu 39/72 Komisija protiv Italije, točka 17., Sud je razdvojio, namjerno ili ne, ta dva termina: »... U skladu s time suprotni su Ugovoru svi načini primjene čija bi posljedica bila prepreka izravnom učinku uredaba Unije i koji bi ugrožavali njihovu istodobnu i jedinstvenu primjenu na području cijele Unije. $\aleph^{3} \mathrm{Ti}-$ jekom razvoja europskog prava (u dokumentima, praksi Europskog suda, teoriji europskog prava) postupno su postojali slučajevi kada su se upotrebljavala oba termina - »izravni učinak« i »izravna primjena« - pri čemu je upitno jesu li se u tim prigodama koristili i kao odvojeni koncepti, kao i slučajevi kada su se koristili i kao sinonimi u terminološkom smislu.

Za Ugovor o osnivanju Europske ekonomske zajednice iz 1957. (11957E/ TXT) postoje četiri vjerodostojna teksta - francuski, njemački, nizozemski i talijanski. Odredbe sadržavaju stipulaciju da uredbe vrijede: njemački - gelten unmittelbar; francuski - applicabilité directe; talijanski - direttamente applicabile; nizozemski - rechtstreeks toepasselijk. Potrebno je uočiti da se rabe ti termini iako postoje termini (njemački - unmittelbare Wirkung;

\footnotetext{
2 https://howlingpixel.com/i-en/Direct_applicability.

3 Predmet 39/72 Commission v. Italy, [1973] ECR 101.
} 
francuski - effets directs; talijanski - effetto diretto; nizozemski - rechtstreekse werking). U engleskoj inačici Ugovora o EEZ-u iz 1972. godine uzima se u obzir razlika između izravne primjene i izravnog učinka. U inačicama iz 1962. i 1967. odredbe Ugovora sadržavaju formulaciju take direct effect, dok kasniji tekst sadržava odredbu: $» A$ regulation shall apply generally. It shall be binding in its entirety and be directly applicable in each Member State.« (tako Winter, 1972, str. 438).

Dojam je da se ta dva koncepta (ako se uopće može govoriti da je u začecima razvoja europskog prava riječ o dvama konceptima), a posljedično i njihovi pripadajući termini, upotrebljavaju u odnosu na vrste konkretnih akata te će se u radu analizirati u odnosu na direktive i uredbe. Velik utjecaj imale su, povijesno gledano, formulacije Ugovora u vezi s uredbama i direktivama koje su zadržane do danas; izravni se učinak definirao u praksi Europskog suda pretežito uz tumačenje direktiva, dok se izravna primjena više veže uz uredbe. U tom smislu u idućim će se poglavljima analizirati koncepti izravne primjene i izravnog učinka u odnosu na te dvije vrste pravnih akata Unije.

\subsection{Izravna primjena direktiva kao posljedica priznavanja izravnog učinka}

Naime, da bismo razjasnili nedoumice, potrebno je ponajprije napomenuti da se, kada se govori o izravnom učinku, misli na horizontalni izravni učinak. Stoga se u ovom radu obrađuje upravo taj koncept. Horizontalni izravni učinak u ovome radu znači da se državljani Unije mogu pozvati na europske odredbe na nacionalnim sudovima, dok će se vertikalni, koji znači da su adresati akta države i njihova tijela ${ }^{4}$, u ovom radu samo uzgredno spomenuti.

Nadalje, treba imati na umu da su direktive glavni alat harmonizacije nacionalnog zakonodavstva (Craig \& de Burca, 2015, str. 279). Primarno direktive imaju posredan učinak koji u praksi sve više jača. Namjera je razvoja i jačanja toga koncepta učinkovitost europskog prava na nacionalnoj razini. Određeni autori iznose tezu da se posredni učinak širi i zasjenjuje horizontalni izravni učinak (Shaw, 2000, str. 446), a u izvjesnoj mjeri i incidentalni učinak (Arnull, 1999, str. 140), a može se reći da posredni

4 Obvezuje ne samo zakonodavna tijela već i sudove i državnu i javnu upravu koja izravno mora primjenjivati direktive, tzv. administrativni izravni učinak (de Wiite, 1999). 
učinak uključuje izravni, odnosno pretpostavlja ga, i svrha su mu u konačnici izravni učinak i izravna primjena. U predmetu Marshall ${ }^{5}$ navedeno je razlikovanje između vertikalnog i horizontalnog učinka. U njemu se razmatralo pitanje direktiva i na temelju njih izvela se definicija horizontalnoga izravnog učinka. Naime, Sud je smatrao da izravni učinak direktive ne postoji protiv pojedinca, već samo protiv države, pa tako direktive imaju samo vertikalni, a ne i horizontalni učinak. Taj stav ima temelj u čl. 288/3. Ugovora o funkcioniranju Europske unije ${ }^{6}$ gdje se navodi da direktive obvezuju samo države članice. Stajalište u slučaju Marshall posljedica je doslovna i vrlo uska tumačenja te odredbe. Odredba nije do kraja jasna jer nije eksplicitno izrečeno može li se na temelju nje nametnuti obveza pojedincima. U predmetu Van Gend en Loos ${ }^{7}$ Sud zauzima bitno mekše stajalište te daje prvu i pravu definiciju (horizontalnoga) izravnog učinka »kao mogućnost pozivanja pojedinca na europske odredbe na nacionalnim sudovima «. Sud ovdje ističe da nemaju sve odredbe direktive izravni učinak, već samo one koje su jasne, detaljne i bezuvjetne. Time otvara i uvodi mogućnost njihova horizontalnoga izravnog učinka, pod pretpostavkama koje je odredio i nabrojio sam Sud (jasnoća, preciznost i bezuvjetnost). Daljnji razvoj prakse Europskog suda pokazuje da se ovisno o slučaju Sud katkad priklanja stavu iz Marshalla, a katkad svom stajalištu iz presude Van Gend. Nadalje, u presudi Von Colson postavljen je zahtjev funkcionalnosti, što znači da Sud smatra da direktiva treba biti potpuno učinkovita s pomoću jake interpretativne obveze, posrednog učinka koji je direktivama primarno i priznat (više u Rodin \& Ćapeta, 2008 te Prechal, 2005 i dr.) U predmetu Von Colson Europski je sud zaključio da je nacio-

${ }^{5}$ Predmet C-271/91 Marshall v. Southhampton and South-West Hampshire Area bealth Authority, (1993) ECR I-4367.

${ }^{6}$ SL C 202, 7. 6. 2016., str. 1-388.

7 Predmet 26/62 NV Algemene Transport- en Expeditie Onderneming van Gend \& Loos v. Netherlands Inland Revenue Administration, (1963) ECR 1, presuda Suda od 5. veljače 1963., str. 9: »... uloga koju Sud ima na temelju čl. 177. čiji je cilj osigurati da nacionalni sudovi jedinstveno tumače Ugovor potvrđuje da su države prihvatile da pravo Zajednice ima ovlast na koju se njihovi državljani mogu pozivati na tim sudovima. Slijedom navedenog valja zaključiti da je Zajednica novi pravni poredak međunarodnog prava u čiju su korist države ograničile, premda u ograničenim područjima, svoja suverena prava i čiji su subjekti ne samo države članice nego i njihovi državljani.« Vidjeti također str. 13: „Činjenica da navedeni članci Ugovora ovlašćuju Komisiju i države članice da protiv države koja nije ispunila svoje obveze podnesu tužbu Sudu ne znači da u tom slučaju pojedinci ne mogu utužiti iste obveze na nacionalnom sudu. Ni činjenica da Ugovor Komisiji osigurava sredstva za ispunjenje obveza upućenih svojim pravnim subjektima također ne isključuje mogućnost da pojedinci utuže povrede tih istih obveza u sporovima među pojedincima na nacionalnim sudovima.« 
nalni sud dužan usklađeno protumačiti interno pravo »u onoj mjeri u kojoj za to ima diskreciju u nacionalnom pravu«.

Također, u prilog tezi o odstupanju od primarnog pravila, Sud je tijekom razvoja svoje prakse izrazio stav o određenim direktivama da se moraju bezuvjetno primjenjivati (vezano uz unutarnje tržište (Direktiva br. 88/361)). Primjerice, u dvama slučajevima iz 1995. o izvozu mjenica izvan Španjolske Sud je smatrao da mjerodavne odredbe obiju direktiva i Ugovora imaju svojstvo da se pojedinci mogu na njih pozivati na nacionalnim sudovima (predmeti C-358, 416/93 Bordesa (1995) ECR I-361, predmet C-163/94, Sanz de Lera (1995) ECR I-4821). U predmetu Ratti ${ }^{8}$ riječ je o reguliranju situacije kada su države članice, ako su propustile valjano provesti direktivu, prekludirane odbiti priznati njezin obvezujući učinak u slučajevima kada je protiv njih pokrenut spor. Ideja je da država članica mora provesti direktivu te, ako je tako postupila, pojedinac treba moći pozvati se na nacionalno provedbeno pravo, što u konačnici ima horizontalni izravni učinak. U odnosu na situaciju da implementirana direktiva ima posredni učinak, to je situacija kada se direktivama priznaje horizontalni izravni učinak čak i kada nisu implementirane. Ako je država članica propustila provesti direktivu, ona se ne može pozivati na propuštanje pa tako negirati njezin obvezujući učinak nakon proteka roka za implementaciju. Također, u brojnim drugim predmetima Europski sud smatra da direktive ipak mogu proizvoditi »sličan učinak « kao i uredbe nakon proteka vremena za njihovu implementaciju ako ih država nije ispravno implementirala. ${ }^{9}$ Nadalje, u predmetu Kortas ${ }^{10}$ Europski je sud odlučio da mogućnost da država članica bude izuzeta od obveze harmonizacije direktive prema čl. 114/4. UFEU-a (bivši čl. 95/4. UEZ-a) ne sprječava da direktiva ima izravni učinak niti prekludira pojedinca u njegovu pravu da se izravno poziva na odredbe direktive, čak ni u situaciji kada je za državu članicu predviđeno odobrenje za izuzeće, a Komisija je neopravdano propustila odgovoriti na njezin zahtjev. Iako je, dakle, riječ o slučaju da država članica nema obvezu implementacije direktive, pojedinac se može pozvati na nju. Horizontalni izravni učinak kod odredaba koje ga inicijalno nemaju

8 Predmet 148/78 Publico Ministero protiv Tulio Ratti, (1979) ECR 1629.

${ }^{9}$ Predmet 8/81 Becker protiv Finanzamt Münster-Innenstadt, (1982) ECR 53; predmet C-141/00 Ambulanter Pflegedienst Kügler GmbH protiv Finanzamt für Körperscaften, (2002) ECH I-6833.

10 Predmet C-319/97 Kortas, (1999) ECR I-3143. Europski je sud smatrao da je tužba protiv Komisije radi kršenja obveza iz članka 265. Ugovora o funkcioniranju Europske unije (bivšeg čl. 232. UEZ-a) odgovarajući pravni lijek. 
omogućuje u izvjesnoj mjeri i čl. 267. Ugovora o funkcioniranju Europske unije (bivši 234. UEZ-a). Na temelju njega moguće je nacionalnim sudovima postavljati pitanja u vezi s mjerama Unije Europskom sudu, a to ima za posljedicu da se na takve akte mogu pozivati pojedinci na nacionalnim sudovima.

Činjenica da odredbe direktive, ako ispunjavaju navedene uvjete, imaju izravnu primjenu navedena je i u predmetu Van Duyn. ${ }^{11}$ Sud smatra u Van Duynu da su direktive obvezujuće te da će biti učinkovitije ako se pojedinci na njih mogu pozivati (funkcionalni razlog). Za predmet Van Duyn Rodin (Rodin \& Ćapeta, 2008, str. 25) navodi: »U vrijeme kada se predmet raspravljao, već je od ranije poznat stav Suda da tadašnji čl. 189. UEZ ne odriče mogućnost da bi direktive mogle imati učinke slične uredbama. « Riječima Europskog suda, »... ako su na temelju odredaba čl. 189. uredbe izravno primjenjive, pa prema tome mogu po samoj svojoj naravi imati izravne učinke, iz toga ne slijedi da i druge kategorije akata navedenih u tom članku ne mogu nikada imati slične učinke.« Sud obrazlaže navedeno shvaćanje načelom korisnog učinka (franc. l'effet utile). Drugim riječima, svaka pravna norma zamišljena je da bi imala učinke. Ako se stranka u postupku ne bi mogla na njih pozivati na nacionalnom sudu, postavlja se pitanje koja je uopće svrha takve norme. S obzirom na to da su direktive obvezujući pravni akti, nije realno da is te strane nemaju mogućnost izravnog učinka. Craig navodi: »... Sud smatra da svi obvezujući akti prava Zajednice mogu imati izravni učinak, dok za druge vrste neobvezujućih akata, ili soft law ne kaže da imaju izravni učinak, ali utječu na druge načine i mogu imati tzv. posredni ili interpretativni učinak.« (Craig \& de Burca, 2015, str. 277).

Uz taj, postoji još jedan razlog za priznavanje horizontalnoga izravnog učinka direktiva, a to je činjenica da bi, ako bi se priznao samo vertikalni, a ne i horizontalni učinak, to dovelo do neujednačene primjene prava unutar države članice i između država članica, čime bi došlo i do diskriminacije između pojedinaca. Također, »... inzistiranje da direktive nemaju horizontalni izravni učinak neminovno dovodi do diskriminacije između javnog i privatnog sektora.« (Mastroianni, 1999, str. 425).

U sudskoj praksi vidljivo je da Europski sud zadržava stajalište, odnosno poštuje pravilo da direktive imaju samo vertikalni izravni učinak koji je određen u čl. 288. Ugovora i u predmetu Marshall, ali vrlo često stvarno otvara prostor za horizontalni izravni učinak (Craig \& de Burca, 2015,

11 Predmet 41/74 Yvonne van Duyn protiv Home Office, (1974) ECR 1337. 
str. 282). ${ }^{12}$ I niz drugih slučajeva pokazuje da Sud inicijalno smatra da je direktiva takve naravi da ne može imati izravni učinak, dok bi se poslije pokazalo da je dovoljno jasna da iz nje proizlaze obveze za državu članicu. ${ }^{13}$ Činjenica je da Sud uvijek polazi od temeljnih pravila, svjestan je da direktive po samom slovu zakona, ex lege, nemaju svojstvo izravnog učinka, ali zbog zahtjeva učinkovitosti u određenim slučajevima odstupa od njega, što nikako ne znači njegovo nepriznavanje. Također, da bi imale izravni učinak, one moraju biti, prema stavu Suda, dovoljno jasne, detaljne i bezuvjetne. To znači da trebaju sadržavati potpunu pravnu obvezu koja se na sudu može izvršiti te tek ako ne postoji provedbeno zakonodavstvo, mogu imati izravni učinak. Nakon ispunjenih pretpostavaka priznaje se horizontalni izravni učinak.

Ono što Sud priznaje iznimno je svojstvo direktiva koje nije priznato nijednom formalnom europskom odredbom. Takvo svojstvo i sličan status u određenim slučajevima postižu i odredbe Ugovora. Europski je sud u predmetu Defrenne ${ }^{14}$ priznao horizontalni učinak čl. 147. Ugovora o funkcioniranju Europske unije (bivši čl. 141. UEZ-a). Europski je sud horizontalni izravni učinak priznao i općim načelima i temeljnim pravima Unije te je također u svojoj praksi, uzimajući u obzir i praksu Europskog suda za ljudska prava, definirao opseg i načine njihove primjene (Craig \& de Burca, 2015, str. 356; Shaw, 2000, str. 331; Kelsen, 1927; Hartly, 2007, str. 132 i dr.). U svim navedenim predmetima problematizira se horizontalni izravni učinak, a njegovim priznanjem i primjenom posljedično dolazi do izravne primjene.

Tako dolazimo do sljedećega koncepta, a to je izravna primjena. Dojam je da, kada Sud analizira horizontalni izravni učinak, barem u navedenim slučajevima, a svakako bi se moglo naći primjera i za suprotne, pa i drukčije teze, pod njim misli i na izravnu primjenu, ne praveći razliku između njih. Kako je već rečeno, ni Ugovor o Europskoj uniji ni Ugovor o funkcioniranju Europske unije ne donose izričito definiciju izravne primjene. Ipak, ona bi se mogla samo implicitno izvesti iz čl. 288/2. Ugovora o funkcioniranju Europske unije koji glasi: »Uredba ima opću primjenu. Obvezujuća je u cijelosti i neposredno se primjenjuje u svim državama članicama.«U skladu s tim člankom izravnu primjenu imaju samo uredbe s

12 Predmet C-91/92 Dori protiv Recreb Srl, (1994) ECR I-3325.

13 Predmet C-236/92 Comitato di Coordinamento per la Difesa della Cava protiv Regione Lambardia, (1994) ECH I-463 i predmet C-365/97 Komisija protiv Italije (1999) ECH I-7773.

14 Predmet 43/75 Defrenne protiv Sabena, (1976) ECR 455. 
obzirom na to da sama svrha i namjera stvaranja direktiva u svojoj esenciji nije izravna primjena. Taj se termin spominje samo uz uredbe pa proizlazi da su uredbe jedini akt koji ima izravnu primjenu prema primarnom zakonodavstvu Unije. U tom smislu Europska unija utvrđuje njihovo područje primjene i učinke koje će proizvoditi u nacionalnim pravnim sustavima država članica (Schutze, 2015, str. 80).

Iz navedenog proizlazi da je izravna primjena svojstvo koje je priznato nekoj odredbi na temelju samog prava, dok je izravni učinak kvaliteta, svojstvo same odredbe koja se procjenjuje od slučaja do slučaja. Kod direktiva je riječ o tome da, ako nisu odgovarajuće ili uopće implementirane u nacionalno zakonodavstvo, odnosno ako ne postoji nacionalni provedbeni propis, a njihove odredbe svojom kvalitetom ispunjavaju uvjete za izravni učinak, doći će do izravne primjene. Takva je situacija podredna samo ako ne postoji mogućnost postupanja u skladu s odredbom Ugovora i pravila iz Marshalla, a radi postizanja učinkovitosti europskog sustava na nacionalnoj razini. S druge strane, u slučaju uredaba riječ je o situaciji da se zbog svojstava koje odredba ima priznaje izravni učinak, pa se posljedično ona izravno primjenjuje. U nastavku ćemo prikazati drukčiju situaciju od one kod direktiva, gdje uredbe na temelju Ugovora imaju izravnu primjenu te im se u pravilu posljedično priznaje izravni učinak ako pojedine odredbe ispunjavaju zahtjeve.

\subsection{Izravni učinak uredaba kao posljedica izravne primjene}

Uredbe su akti Europskoga parlamenta i Vijeća i, kako je već navedeno, u čl. 288/2. Ugovora o funkcioniranju Europske unije propisano je da uredbe imaju opću primjenu, da su u cijelosti obvezujuće i izravno se primjenjuju u svim državama članicama. »One su neindividualizirane zakonodavne mjere koje imaju izravni učinak na nacionalni pravni poredak, bez potrebe donošenja nacionalnih provedbenih propisa. Njihovo osposobljavanje za stavljanje na snagu, nije potrebno, a štoviše, nije niti dozvoljeno ... Temeljem tako osmišljenog koncepta izravne primjene, uvođenje odredbi uredaba u nacionalno zakonodavstvo je nepotrebno, pa čak i zabranjeno.« (Winter, 1972, str. 436). Winter također navodi da države članice imaju vrlo malo manevarskog prostora za postavljanje »prepreka« te da je s pozicije pojedinaca uredba vrlo slična zakonu.

U posljednjih 50 godina i u međunarodnom pravu dogodila se promjena. Iako danas i međunarodno pravo poznaje izravni učinak, do toga je 
došlo razvojem prava. Prije se radi učinkovitosti međunarodnih akata na nacionalnoj razini smatralo da svaki međunarodni instrument zahtijeva neki oblik intervencije države u smislu uvođenja u nacionalno zakonodavstvo, neovisno o tome je li riječ o monističkom ili dualističkom sustavu (monistički smatra da nacionalno i međunarodno pravo čine jedinstven pravni sustav te međunarodno pravo postaje automatski dijelom nacionalnog prava od trenutka ratifikacije, bez potrebe za daljnjim mjerama za transponiranje, dok dualistički gleda na pravni sustav međunarodnog i pravni sustav nacionalnog prava kao na dva odvojena pravna poretka te međunarodno pravo ne postaje obvezno kao dio domaćeg prava dok ne bude transponirano domaćim propisima). (Winter, 1972, str. 435).

Ta činjenica ilustrira u kojoj je mjeri pravo Unije novost u međunarodnom pravu i pomiče granice tradicionalnog shvaćanja međunarodnog prava. Tek kada se ta pravila prihvate unutar nacionalnoga pravnog poretka, postavlja se pitanje imaju li međunarodne odredbe svojstvo da ih sudovi na nacionalnoj razini mogu primjenjivati. Svrha je koncepta »izravno primjenjiv« iz čl. 288. osloboditi države članice obveze preuzimanja odredaba u nacionalno zakonodavstvo provedbenim mjerama. Uredba je osmišljena da ima opću primjenu i da njezina primjena bude obvezatna u cijeloj Uniji te da se time jedinstveno primjenjuje na cijelom području Unije. Izravna primjena koja je inherentna uredbama na temelju članka 288. ima za posljedicu izravan ulazak u nacionalni pravni sustav države članice.

Sud Europske unije potvrdio je u predmetu Antonio Muòoz y Cia SA i Superior Fruiticola SA protiv Frumar Ltd and Redbridge Produce Marketing Ltd [2002] ECR I-7289, toč. 23., da uredbe imaju i izravni učinak i pojasnio da taj izravni učinak može biti vertikalan i horizontalan. Tu je tvrdnju naveo pozvavši se na članak 288. Ugovora o funkcioniranju Europske unije (Hartley, 2007, str. 293). U predmetu Munoz Sud navodi da zahvaljujući njihovoj pravnoj prirodi i položaju u okviru europskih pravnih izvora, uredbe utvrđuju prava pojedinaca koja nacionalni sudovi imaju zadaću štititi (C-253/00 t. 27).

Međutim, postavlja se pitanje kako objasniti očiglednu kontradiktornost između tvrdnje da se uredba izravno primjenjuje i priznanja da u praksi velik broj odredaba uredaba ipak nije izravno primjenjiv (Mathijsen, 2013, str. 184). Da bi se riješio taj problem, nije potrebno ni poželjno tvrditi da se odredbe uredbe koje ne ispunjavaju kriterij complete and legally perfect ne bi trebale nalaziti u uredbama, već direktivama ili odlukama koje se upućuju državama članicama (Winter, 1972, str. 434). Ponajprije treba imati na umu da termin directly applicable iz čl. 288. označava drugi kon- 
cept u odnosu na koncept izravnog učinka. U pravilu bi se moglo reći da je izravni učinak posljedica izravne primjene koja je ex lege priznata uredbama na temelju čl. 288. U većini slučajeva to i jest tako jer je izravni učinak i namjera u pogledu uredaba s obzirom na to da su one, kao i direktive, obvezujući pravni akti. Međutim, to bi značilo da se cijela uredba sastoji od odredaba koje su complete and legally perfect ili, drugim riječima, da su uredbe uvijek same po sebi, koristeći se starijom terminologijom, self-executing (Pescatore, 1972, str. 28). Takav zaključak ne bi mogao biti točan. Moguće je da neka uredba, koja u skladu sa svojom pravnom naravi ima izravnu primjenu, ipak ne sadržava tzv. odredbe koje su self-executing (tj. koje su jasne, detaljne i bezuvjetne, čime se omogućuje pojedincu izravna i neposredna primjena prava i obveza), a time nema ni izravni učinak. Jednako tako, moguće je da direktiva, koja, sjetimo se, po definiciji iz čl. 288. i tumačenja iz predmeta Marshall, nije izravno primjenjiva sadržava odredbe koje su self-executing; koje su stoga izravno primjenjive i imaju izravni učinak. Kao i kod direktiva dolazi do iste situacije: može li se pojedinac pozvati na pojedine odredbe akta, a ne na cijeli akt? Moraju li i imaju li sve odredbe koje na temelju prava imaju izravnu primjenu i svojstva da proizvode pravne učinke? Znači li to da odredba čl. $288 / 2$. Ugovora, koja propisuje da se uredbe izravno primjenjuju u svim državama članicama, samim time uredbama priznaje izravni učinak? Kod direktiva se očekuje da nemaju, ali kod uredaba se očekuje da imaju iako to ne mora uvijek biti slučaj jer sve odredbe predmetnog akta nisu i ne moraju imati svojstvo jasnoće, detaljnosti i bezuvjetnosti. Kod uredaba čini se da je obratna situacija u odnosu na situaciju kod direktiva. Uredbe, odnosno njihove odredbe, ex lege imaju izravnu primjenu, pa se očekuje da imaju izravni učinak na stranke uz napomenu da trebaju, a nomotehnički i moraju imati, bar u dijelu supstancijalnih odredaba, svojstva detaljnosti, bezuvjetnosti i jasnoće.

Winter je te tvrdnje naveo puno prije, a današnji praktičari slično navode što bi bila izravna primjena: »Izravna primjena sada znači da za uredbe nisu potrebni nacionalni provedbeni propisi ... ako je namjera izravnog učinka ikada bila da bude posljedica izravne primjene ... « ${ }^{15}$ Ta tvrdnja otvara ne samo pitanje razlikovanja između tih koncepata nego i pitanje impliciraju li oni jedan drugi te koji kojemu prethodi. To se vidi u brojnim slučajevima gdje uredbe često sadržavaju brojne odredbe koje u praksi zahtijevaju daljnje mjere implementacije koje države članice trebaju donijeti

15 https://howlingpixel.com/i-en/Direct_applicability. 
ili čak sama tijela Unije kako bi bile dovoljno jasne, precizne i bezuvjetne da ih nacionalni sudovi mogu primijeniti u postupcima. U predmetu 34/73 Variola protiv Italian Finance Administration (1973) ECR 981 Sud je smatrao (str. 900): »Izravna primjena uredbe znači da njezino stupanje na snagu i njezina primjena u prilog ili protiv tih subjekata na koje se odnosi ne ovisi ni o kakvim mjerama uvođenja u nacionalno pravo ... države članice dužne su ne ometati izravnu primjenu koja je svojstvena uredbama. Striktno poštivanje te obveze bitan je uvjet za istodobnu i jedinstvenu primjenu na području cijele Unije.« Nadalje, postoje primjeri gdje se izričito uvjetuje primjena uredbe preuzimanjem u nacionalno zakonodavstvo. Uredba Vijeća 1463/70 SL 1070, str. 482, određuje: »Države članice dužne su pravovremeno i po savjetovanju s Komisijom donijeti zakone i druge akte koji su potrebni za provedbu ove Uredbe.«U čl. 19. Uredbe (EU) 2019/1021 Europskog parlamenta i Vijeća od 20. lipnja 2019. o postojanim organskim onečišćujućim tvarima navodi se sljedeće: »Svaka država članica imenuje nadležno tijelo ili tijela odgovorna za administrativne zadaće i provedbu koji su potrebni u skladu s ovom Uredbom. Ona obavješćuje Komisiju o takvu imenovanju najkasnije tri mjeseca nakon stupanja na snagu ove Uredbe, osim ako je to već učinila prije stupanja na snagu ove Uredbe te je također obavješćuje o svakoj promjeni u pogledu imenovanog nadležnog tijela.« Također, Uredba (EU) 2019/1020 Europskog parlamenta i Vijeća od 20. lipnja 2019. o nadzoru tržišta i sukladnosti proizvoda i o izmjeni Direktive 2004/42/EZ i uredbi (EZ) br. 765/2008 i (EU) br. 305/201 sadržava sljedeću odredbu: »Države članice utvrđuju pravila o sankcijama koje se primjenjuju na kršenja ove Uredbe i zakonodavstva Unije o usklađivanju iz Priloga II., a kojima se nameću obveze gospodarskim subjektima te poduzimaju sve potrebne mjere radi osiguranja njihove provedbe u skladu s nacionalnim pravom.« Također, države članice uspostavljaju postupke za pružanje informacija o prenošenju zakonodavstva Unije o usklađivanju, utvrđuju sankcije za nepoštivanje odredaba uredaba te na taj način zahtijevaju također brojne radnje radi usklađivanja nacionalnog prava s europskim tako da se razvojem prava promijenilo shvaćanje da je postojanje uredbe u nekom području koju je donijela Europska unija u pravilu znak za »isključivanje pristupa nacionalnog zakonodavstva (Winter, 1972, str. 429). Nadalje, usprkos tome što velik broj odredaba uredaba ima svojstvo horizontalnoga izravnog učinka i nacionalni ih sudovi mogu primjenjivati na pojedince, moguće je da uredbe sadržavaju odredbe za koje se želi da imaju samo vertikalni izravni učinak. Tako nije isključeno da one odredbe uredbe kojima nije bila namjera da proizvode horizontalni izravni učinak ipak imaju određen ograničeni 
učinak u odnosima između država članica i pojedinaca pod njihovom jurisdikcijom (Everling, 1967, str. 466).

Jasnim se čini da je čl. 288. pisan kao uputa za europska tijela koja stvaraju propise, ali i za same države članice. Naime, unaprijed davati svojstvo odredbama nekoga pravnog akta da se mora moći izravno primijeniti nije samo uputa primjenjivaču prava, već ponajprije piscima odredaba, koje moraju imati svojstvo jasnoće, preciznosti i bezuvjetnosti. Primjenjivači prava, s druge strane, imaju olakšan posao ako se susretnu s takvom odredbom. Njima i nije potrebna neka posebna uputa da bi uočili svojstva odredbe. Problematično je u slučaju kada bi odredba trebala imati takva svojstva, a nema ih. Iz iskustva primjene i direktiva i uredaba pokazuje se da je vrlo često potrebno, bez obzira na vrstu akta, primijeniti određenu odredbu kako bi europska odredba bila učinkovita i u onim slučajevima kada postoje nedostaci u njezinu prenošenju u nacionalni pravni sustav.

\subsection{Izravni učinak i izravna primjena direktiva kao posljedica povezanosti uredaba i direktiva}

Određena pravna nesigurnost za privatne stranke proizlazi iz pravila Unije jer je neko područje istodobno regulirano odredbama uredaba i direktiva. Tako temeljna odredba može biti sadržana u uredbi, a dalje regulirana u drugim uredbama ili direktivama ili obratno, temeljna se odredba može nalaziti u direktivi, a biti regulirana uredbama koje je možda detaljnije uređuju. Također postoje slučajevi kada uredbe upućuju na direktive i obratno. Potonje je važno s obzirom na to da uredbe imaju i horizontalni i vertikalni izravni učinak. Primjer je predmet Viamex ${ }^{16} \mathrm{u}$ kojem se uredba poziva na direktivu. U direktivi se utvrđuju pravila o zaštiti životinja tijekom njihova prijevoza. Europski sud navodi da se direktivom ne mogu određivati prava i obveze za pojedince, ali »da to ne sprječava, u načelu, primjenu odredaba direktive na način da se na njih izričito poziva u uredbi, ako se poštuju temeljna načela prava, a posebno načelo pravne sigurnosti.« Financijski se sud u Hamburgu (Finanzgericht Hamburg) nije slagao s učincima pozivanja na direktivu u uredbi. Međutim, Europski sud to nije smatrao povredom načela pravne sigurnosti jer je svrha pozivanja na direktivu bila osigurati, radi implementacije uredbe, usklađenost s mjerodavnim odredbama direktive. Pozivanje na direktivu ograničeno je samo na te odredbe. Posljedica je

16 Predmeti C-37/06 i C-58/06 Viamex Agrar Handels GmbH i Zuchtvieh-Kontor GmbH (ZVK) protiv Hauptzollamt Hamburg-Jonas, (2008) ECR I-69. 
bila da je na temelju odredbe za privatne stranke nastala obveza koja inače ne bi postojala. Odluka označava daljnji razvoj temeljnog pravila da se direktivama ne određuju prava i obveze za pojedince. Činjenica je da, iako je temeljno pravilo iz Ugovora derivirano, u slučaju pozivanja uredbe na neke odredbe direktive te odredbe imaju izravni učinak za privatne stranke. Takav izravni učinak direktiva svjesno je prihvaćen kako bi se osigurala učinkovitost prava EU-a. Predmet Viamex otvara pitanje pravne nesigurnosti s obzirom na to da je sud koji se obratio Europskom sudu postavio pitanje odnosi li se plaćanje koje je trebalo biti izvršeno na cijelu direktivu. Europski je sud odgovorio da su mjerodavne samo one odredbe koje se odnose na svrhu uredbe. Riječ je o uredbi koja se općenito poziva na direktivu te je potrebno "nagađati« koje odredbe direktive zaista određuju obveze za privatne stranke. Osim tog slučaja moguće je zamisliti slučajeve gdje se uredba poziva na manje obvezatne odredbe direktive te slučajeve kada uredba formalno specificira usklađenost s direktivom. Posljedično je problematično međusobno usklađivanje odredaba direktive i uredbe, pri čemu raste stupanj pravne nesigurnosti.

Nadalje, slijedi još jedan primjer odnosa i povezanosti uredbe i direktive, odnosno primjer izmjene teksta direktive uredbom. Takve kombinacije više nisu rijetkost u novijem zakonodavstvu Unije: Uredbom Komisije (EU) 2019/554 od 5. travnja 2019. o izmjeni Priloga VI. Direktivi 2007/59/EZ Europskog parlamenta i Vijeća o davanju ovlaštenja strojovođama koji upravljaju lokomotivama i vlakovima na željezničkom sustavu Zajednice (Tekst značajan za EGP) zamjenjuje se točka 8. Priloga VI. Direktive 2007/59/EZ. Kod hrvatskog Nacrta prijedloga zakona o sigurnosti i interoperabilnosti željezničkog sustava, između ostalih odredaba sadržanih u većem broju direktiva, uredaba i odluka, neke su preuzete tim zakonom, a neke nacionalnim podzakonskim aktom, konkretno pravilnikom koji predmetni zakon predviđa. S obzirom na to da je navedena točka 8. Priloga IV. Direktive već bila preuzeta pravilnikom, bilo je radi usklađivanja potrebno odgovarajuće izmijeniti i odredbe pravilnika stavljajući izvan snage postojeće koje nisu u skladu s donesenom Uredbom. Primjer je samo ukratko naznačen da se ilustrira povezanost materije europskog prava koja se nalazi u različitim vrstama akata te da se pokaže kako takav način pisanja ima utjecaj i mora se uzeti u obzir i u izradi nacionalnog zakonodavstva koje mora u svim segmentima biti harmonizirano.

S obzirom na navedeno, u teoriji se često postavlja pitanje postoji li i dalje potreba razlikovanja uredaba i direktiva jer je mišljenje brojnih stručnjaka da ta razlika dovodi do pravne nesigurnosti i nejednakosti stranaka. Ipak, Craig i de Burca smatraju da se priznavanjem izravnog učinka direktivama 
nije izgubila razlika između uredaba i direktiva, već se dobila veća pravna sigurnost (Craig \& de Burca, 2015, str. 284; Craig, 2009 i dr.).

\section{Recentni zakonodavni primjer odstupanja od izravne primjene, obvezatnosti i izravnog učinka uredbe}

U daljnjem tekstu bit će naveden recentni primjer na kojem će se propitati način shvaćanja koncepata izravne primjene i izravnog učinka uredaba. Naime, Komisija je dvije godine prikupljala podatke od država članica kako bi riješila problem što pogranična područja ostvaruju gospodarski lošije rezultate od drugih područja. Neke su države članice poduzimale različite pojedinačne, bilateralne ili čak multilateralne inicijative za uklanjanje pravnih graničnih prepreka, ali to nije bio slučaj kod svih država članica niti je intenzitet tih nastojanja bio jednak. Vezano za to pitanje, a zbog problema s financiranjem, pristupom javnim uslugama te dotadašnjim negativnim iskustvima Komisija je donijela priopćenje »Poticanje rasta i kohezije u graničnima regijama EU-a« (priopćenje o graničnim regijama). ${ }^{17} \mathrm{U}$ vezi s navedenom tematikom postojala je $\mathrm{i} »$ Europska teritorijalna suradnja«, program koji je od 1990. poznat pod nazivom Interreg. ${ }^{18}$ Njime se pruža potpora programima prekogranične suradnje u pograničnim regijama Unije, uključujući u onima sa zemljama EFTAe. Materija je još regulirana sljedećim dokumentima: Uredba (EZ) br. 1059/2003 Europskog parlamenta i Vijeća od 26. svibnja 2003. o uspostavi zajedničkog razvrstavanja prostornih jedinica za statistiku (NUTS) ${ }^{19}$, Uredba (EZ) br. 45/2001 Europskog parlamenta i Vijeća od 18. prosinca 2000. o zaštiti pojedinaca u vezi s obradom osobnih podataka u institucijama i tijelima Zajednice i o slobodnom kretanju takvih podataka ${ }^{20}$, Ured-

17 U njemu se ističu načini na koje EU i države članice mogu smanjiti složenost, potrebno vrijeme i troškove prekogranične interakcije te promicati ujedinjavanje usluga uz unutarnje granice. Razmatra se što je potrebno poboljšati kako bi građani i poduzeća u graničnim regijama mogli potpuno iskoristiti prigode na obje strane granice. U komunikaciji se predlaže akcijski plan od 10 točaka od kojih je jedna posebno usmjerena na pravne i administrativne granične prepreke. Priopćenje Komisije Vijeću i Europskom parlamentu »Poticanje rasta i kohezije u graničnim regijama EU-a«-COM(2017) 534 final, 20. 9. 2017.

\footnotetext{
18 https://projekti.hr/hr/program-financiranja/interreg.

19 SL L 154, 21. 6. 2003., str. 1.

20 SL L 8, 12. 1. 2001., str. 1 .
} 
ba (EU) br. 182/2011 Europskog parlamenta i Vijeća od 16. veljače 2011. o utvrđivanju pravila i općih načela u vezi s mehanizmima nadzora država članica nad izvršavanjem provedbenih ovlasti Komisije. ${ }^{21}$

Usprkos svim postojećim dokumentima smatra se da »države članice ne mogu u dostatnoj mjeri ostvariti ciljeve predložene mjere na središnjoj ili regionalnoj i lokalnoj razini, već se, zbog njezina raspona ili učinka, ti ciljevi mogu bolje ostvariti na razini Unije.« Navod je to iz Prijedloga uredbe Europskog parlamenta i Vijeća o mehanizmu za uklanjanje pravnih i administrativnih prepreka u prekograničnom kontekstu (Strasbourg, COM (2018), 373 final, 2018/0198 (COD)) u pogledu kojeg je zakonodavni postupak započeo još 29. 5. 2018., a taj pravni dokument još nije stupio na snagu. Prijedlog uredbe regulira područje primjene Interrega, programa koji je pokrenut radi jačanja učinaka kohezijske politike Europske unije od 2014. do 2020. i nasljednik je programa INTERREG IVc koji je bio aktivan u prošlome programskom razdoblju. Ima cilj smanjiti postojeće nejednakosti između regija Europske unije u njihovu ekonomskom i društvenom razvoju i održivosti okoliša, pritom uzimajući u obzir njihove specifične prostorne karakteristike i mogućnosti. S obzirom na postojeće zatečeno stanje, a i sam sadržaj, riječ je o području i materiji koja ne može po prirodi stvari na jednak način biti propisana za sve države članice upravo zbog postojanja razlika u stanjima u pograničnim područjima. Stoga je predviđena mogućnost da svaka država članica odluči za sebe hoće li se u postizanju cilja iz Uredbe služiti tim dopunskim mehanizmom ili će primjenjivati već postojeće mehanizme, ovisno o uvjetima.

Sporno je i nedovoljno jasno da je uporaba posebnog mehanizma uspostavljenog tom Uredbom dobrovoljna. Država članica može odlučiti da će na određenoj granici s jednom ili više susjednih država članica nastaviti rješavati pravne prepreke u određenoj prekograničnoj regiji u okviru djelotvornih mehanizama koje je uspostavila na nacionalnoj razini ili koje je formalno ili neformalno uspostavila s jednom ili više država članica. U tom slučaju može odlučiti ne primjenjivati mehanizam uspostavljen tom Uredbom. U drugom slučaju, država članica može odlučiti na određenoj granici s jednom ili više susjednih država članica da će se pridružiti postojećemu djelotvornom mehanizmu koji je formalno ili neformalno uspostavila jedna susjedna država članica ili više njih. Ako se u okviru tog mehanizma dopušta pridruživanje, ona opet može odlučiti da ne primjenjuje mehanizam uspostavljen na temelju te Uredbe. Nadalje, ako država člani-

21 SL L 55, 28. 2. 2011., str. 13. 
ca odluči na određenoj granici s jednom ili više susjednih država članica da će se pridružiti postojećemu djelotvornom mehanizmu koji su formalno ili neformalno uspostavile jedna ili više susjednih država članica, pod uvjetom da je pristupanje tom mehanizmu dopušteno, ona ni u tom slučaju ne mora odabrati mehanizam uspostavljen predmetnom Uredbom. ${ }^{22}$

S obzirom na materiju i očekivani fakultativni način primjene odredaba upitno je može li se za tu problematiku rabiti uredba kao pravni akt Unije. $\mathrm{Na}$ to se pitanje pokušalo dati odgovor u obrazloženju samog Prijedloga uredbe. Naime, navodi se da se Prijedlogom uredbe utvrđuju obveze država članica za uspostavu, za svaku granicu sa susjednom državom članicom, mehanizma za uklanjanje pravnih prepreka u zajedničkoj prekograničnoj regiji i istodobno im se dopušta provedba drugih učinkovitih mehanizama. Preporuka ne bi bila najučinkovitiji instrument jer, navodi se, preporuke u skladu s čl. 288/5. UFEU-a nemaju obvezujuću snagu. Smatra se da ni direktiva ne bi bila najučinkovitiji instrument jer je obvezujuća samo što se tiče rezultata koji je potrebno postići, a odabir je oblika i metoda postizanja tog rezultata u skladu s čl. 288/3. UFEU-a prepušten nacionalnim tijelima, što bi, navodi se, moglo dovesti do stvaranja različitih sustava na unutarnjim granicama. U obrazloženju se navodi da bi se direktivom mogle stvoriti nove razlike u graničnim regijama. ${ }^{23}$ Budući da se pravna snaga preporuka još uvijek shvaća prilično formalistički, pa se govori o pravno neobvezujućim aktima, a kako i jesu definirane čl. 288. UFEU-a, koji se čak i kada se koriste u tumačenju pravnoobvezujućih akata u praksi ne smatraju relevantnima, ta se materija ne može u sadašnjim uvjetima regulirati ni tom vrstom akata, navodi se u obrazloženju.

S obzirom na interes da se postigne cilj uredbe s jedne strane te različite uvjete država članica s druge strane, daje se mogućnost da države članice izaberu korištenje nekim od mehanizama. Ipak im se ne ostavlja moguć-

22 Čl. 4. Moguénosti država članica za uklanjanje pravnih prepreka: (1) Država članica odlučuje se za mehanizam ili za postojeće načine za uklanjanje pravnih prepreka koje sprječavaju provedbu zajedničkog projekta u prekograničnim regijama na određenoj granici s jednom ili više susjednih država članica. (2) Država članica može, u pogledu određene granice s jednom ili više susjednih država članica, odlučiti i da će se uključiti u postojeći djelotvoran način koji je formalno ili neformalno uspostavila jedna ili više susjednih država članica. (3) Države članice mogu primjenjivati mehanizam i u prekograničnim regijama uz morske granice ili u prekograničnim regijama između jedne ili više država članica i jedne ili više trećih zemalja ili jedne ili više prekomorskih zemalja i teritorija. (4) Države članice obavješćuju Komisiju o svakoj odluci donesenoj na temelju ovog članka.

${ }^{23}$ Vidjeti str. 5 i dalje Prijedloga uredbe Europskog parlamenta i Vijeća o mehanizmu za uklanjanje pravnih i administrativnih prepreka u prekograničnom kontekstu, 29. 5. 2018., Strasbourg, COM (2018), 373 final, 2018/0198 (COD). 
nost nekorištenja ikakvim mehanizmom i izostanka bilo kakve suradnje. $\mathrm{U}$ tom smislu možemo navedenu situaciju razmotriti s dvaju aspekata: prvo, razvoj odnosa koje regulira pravo Unije svakako mora imati određene reperkusije i za pravila pisanja i izrade pravnih akata te uobičajene i propisane načine njihova shvaćanja i primjene. Svrha je nastanka i postojanja europskog prava zaštititi prava i interese građana, postići ciljeve radi kojih i postoji Unija. Jednom od važnijih karakteristika cijeloga tog pravnog sustava pokazalo se nepostojanje, odnosno rušenje formalističkih načina poimanja prava i postupanja koji su snažno vidljivi u gotovo svim nacionalnim pravnim sustavima (Capeletti, 1989, str. 8). Budući da se cilj, ako prihvatimo objašnjenje iz samoga popratnog teksta propisa, ne bi mogao postići drugim pravnim aktima i njihovim karakteristikama, odnosno ponajprije pravnom snagom koja im je dodijeljena, čini se da je i ta Uredba na tragu takva poimanja i takva provođenja prava. Najveća takva odstupanja uočena kod direktiva proizišla su iz shvaćanja i interpretacije samog Suda koji je upravo kao tijelo koje ima ingerenciju interpretacije, a samim time i usmjeravanja i razvoja prava, pokazao da su ciljevi i zaštita prava ispred forme i u pogledu kojih neke temeljene odredbe imaju naizgled pojednostavnjene stipulacije. Moguće je da u tom smislu možemo razmatrati i taj Prijedlog uredbe, uočavajući da je i u ovom slučaju cilj prevladao formu i u pisanom zakonodavstvu Unije.

Drugi način viđenja, koji u biti i ne isključuje prvi, može biti sljedeći: da je obvezatno provođenje nekog od mehanizama, ponajprije postojećih, ili ovisno o konkretnoj situaciji u određenom području, podredno je obvezna primjena mehanizma utvrđena Prijedlogom te uredbe. Obvezatnost i dalje postoji u odnosu na sam akt u cijelosti, ali s obzirom na njegov sadržaj odnosno pojedine odredbe također postoji, ali ne bezuvjetno. U tom smislu one sve imaju izravnu primjenu, ali je jasno da zbog nepostojanja bezuvjetnosti kao jednog od triju bitnih svojstva izravnog učinka, one ga nemaju niti proizvode takve posljedice. Odredbe jesu jasne i precizne, ali nisu bezuvjetne: uvjet je da se ne primjenjuju neke druge odredbe iz drugih akata kojima bi se mogao postići isti cilj. Obvezne su podredno i tek onda imaju izravnu primjenu i izravni učinak, ako je postojao uvjet i on se ispunio. U tom smislu samo obrazloženje o izboru vrste akta ne bi bilo zadovoljavajuće iako je otvoreno pitanje koja bi vrsta akta bila najprimjerenija. Možda bi se cijeli sadržaj mogao drukčije formulirati, primjerice tako da se direktivom postave ciljevi i preporukom ponude modusi dolaženja do postavljenog cilja. U svakom slučaju, taj akt, ako ikada bude donesen, izazvat će vrlo vjerojatno brojna pitanja, a upitna će biti i njegova primjena i finalno postizanje i mjerenje ciljeva. 


\section{Zaključak}

U želji za što većom učinkovitošću europskog prava na nacionalnoj razini europsko pravo preuzelo je mehanizme iz međunarodnog prava te ih razvilo i prilagodilo. Tako su koncepti izravnog učinka i izravne primjene preuzeti, prošireni i derivirani u odnosu na svoje matično okružje međunarodnog prava. Kao posljedica prijenosa dijela suverenosti država članica na Uniju, Unija ima mogućnost donošenja obveznih propisa, ponajprije uredaba i direktiva, te zahtijevanja njihove učinkovite primjene. Uredbe su, stoga, od samih početaka trebale imati ulogu sličnu onoj kakvu imaju zakoni na nacionalnoj razini, bez mogućnosti zakonodavnog »upletanja« ili kao »oslobođenje od obveza« država članica da donose provedbeno nacionalno zakonodavstvo. Takav intenzitet izravne primjene u samim začecima međunarodnog prava u opsegu kako ga daje europsko pravo nije postojalo, a i danas ima ovisno o sustavu veću ili manju mogućnost izravne primjene. U svakom slučaju, ne postoji takav stupanj prijenosa ovlasti koji bi omogućio takvu razinu obvezatnosti koja je posljedica izravne primjene kod uredaba, čak ni u monističkome pravnom sustavu. Što se tiče direktiva, riječ je također o pravima i obvezama u određenim područjima koja Unija želi ustanoviti i provesti, ali ipak ostavlja prostor državama članicama da same odaberu oblike i metode kako će to ostvariti. To čini s pomoću interpretativne obveze, posrednog učinka koji sve više jača u želji da se ostvari učinkovitost europskog prava. Krajnja je posljedica tog učinka ponovno izravni učinak te posljedično i izravna primjena.

Budući da je cilj ovoga rada bila analiza koncepata izravnog učinka i izravne primjene kod uredaba i direktiva, na primjerima iz razvoja europskog prava pokušao se utvrditi sadržaj tih koncepata, njihova definicija te otkriti postoje li razlike između njih. Razvojem prava pokazuje se da oni više nisu sinonimi iako su u određenim razdobljima tako shvaćani, a tako ih u određenoj mjeri i danas shvaćaju neki teoretičari i praktičari. Iz analiziranih pisanih zakonodavnih odredaba i prakse Europskog suda proizlazi da je izravna primjena svojstvo koje je priznato nekoj odredbi na temelju samog prava, dok je izravni učinak kvaliteta, svojstvo same odredbe koja se procjenjuje od slučaja do slučaja, »da se izravni učinak odnosi na mogućnost državljana država članice Europske unije da ostvare prava zajamčena europskim odredbama izravno pred nacionalnim sudovima. Drugim riječima, ako odredbe ispunjavaju zahtjeve da proizvode izravni učinak, obveza je nacionalnih sudova da priznaju prava koja su državljanima priznata temeljem tih odredaba. S druge strane, izravna primjena odnosi se na činjenicu da neka europska odredba postaje sastavnim dijelom nacio- 
nalnog prava države članice, bez potrebe donošenja provedbenih odredaba. Izravna primjena jest prema tome svojstvo akta odnosno europske odredbe za čiju primjenu u načelu nije potreban provedbeni nacionalni propis.« (Edwards, 2016).

U skladu s navedenim može se postaviti pitanje je li uopće definicija izravnog učinka i izravne primjene jednaka što se tiče uredaba i direktiva? Čl. 288. Ugovora o funkcioniranju Europske unije načelno daje uredbama svojstvo izravne primjene, a tek posljedično horizontalni izravni učinak, a u pogledu direktiva naglašava samo obvezu harmonizacije od država članica, čime im, na temelju gramatičke interpretacije, odriče oba svojstva. Ipak, takvo se pojednostavnjeno definiranje već od samih početaka europskog prava pokazalo neodgovarajućim ili barem nedostatnim i, usudili bismo se reći, neodrživim. U praksi se pokazalo da, iako se direktivama ne priznaju ex lege ni izravni učinak ni izravna primjena, one u slučaju nepostojanja odgovarajućih provedbenih propisa te ispunjavanja određenih uvjeta (jasnoće, preciznosti i bezuvjetnosti) mogu imati horizontalni izravni učinak te se primjenjivati i bez provedbenoga nacionalnog zakonodavstva. Uredbe pak, iako načelno imaju priznatu izravnu primjenu na temelju Ugovora, ne moraju imati i često nemaju izravni učinak jer sve njihove odredbe ne ispunjavaju zahtjeve za njega (jasnoće, preciznosti i bezuvjetnosti), ili se državama članicama ex lege određuje obveza implementacije nekih odredaba, odnosno poduzimanje nekih mjera. $\mathrm{U}$ radu je u prilog toj tezi naveden i primjer recentnoga zakonodavnog prijedloga gdje uredba sadržava odredbe koje nemaju karakteristiku bezuvjetnosti, pa time nemaju izravni učinak, a nemaju ni karakteristiku obvezatnosti, te je upitna i njihova izravna primjena.

Uzimajući u obzir te činjenice, u radu se dolazi do zaključka da se definicija izravnog učinka u znatnoj mjeri profilirala praksom Europskog suda što se tiče direktiva, koje ga striktno gledajući i nemaju, te posljedično, ispunivši pretpostavke za izravni učinak, stječu izravnu primjenu, dok se definicija izravne primjene profilirala na temelju uredaba koje su to svojstvo dobile na temelju prava i koje im ne mora po prirodi stvari dati izravni učinak. Ne može se na temelju zakona propisati i poštivati da neka odredba ima svojstva unaprijed, ex lege, ako se u praksi događa da ona to nema. Tako se pokazalo na slučaju direktiva da je izravna primjena posljedica priznata izravnog učinka. Na primjeru uredaba pokazalo se da sama činjenica da se odredbi priznaje svojstvo izravne primjene ne omogućava ostvarivanje prava na temelju nje ako formulacija odredbe nije dovoljno jasna, precizna i bezuvjetna. U slučaju direktiva izravni učinak nastupa u biti tek 
djelovanjem posrednog učinka, i to ako su ispunjene pretpostavke, a ne postoji provedeno nacionalno zakonodavstvo. Drugim riječima, iznimno, kada je od važnosti za funkcioniranje europskoga pravnog sustava na nacionalnoj razini, a zbog neimplementacije ili nepravilne implementacije nije moguće primijeniti nacionalno provedbeno zakonodavstvo. Nepostojanje svojstva izravnog učinka s pozicije uredaba također je iznimka od pravila jer je ipak činjenica da većina ima svojstva da proizvodi pravne učinke među strankama. Dojam je da se gube razlike između uredaba i direktiva te se nameće pitanje u brojnim teorijskim i stručnim raspravama treba li se objema priznati izravni učinak ili postoji i dalje razlog za opstanak prvotnih temeljnih pravila iz čl. 288. Ipak, odgovor se nudi razumijevanjem sekundarnog i primarnog zakonodavstva Unije, a posebice pomnim praćenjem i razumijevanjem prakse Europskog suda. Europski sud, kao sukreator europskog prava i kao tijelo nadležno za njegovo tumačenje, ne shvaća temeljna pravila kao ograničavajući čimbenik jer ih istodobno i poštuje, ali i odstupa od njih zbog učinkovitosti i svrhovitosti te ostvarenja ciljeva europskog prava, uz napomenu da to čini u točno određenim uvjetima. Europski sud teži dokinuti i dovesti u pitanje sva tumačenjska pravila koja bi se svodila na formalističko poimanje prava i takvu primjenu pravila koja bi bila oličenje svojevrsne ontološke dosljednosti; u kojima bi se ogledavalo doslovno poštivanje pravila, bez obzira na pravne posljedice koje će to prouzročiti (Kühn, 2004, str. 532; Hesselink, 2001, str. 20; Kulcsár, 2001, str. 41 itd.). U tom se kontekstu trebaju promatrati i koncepti izravnog učinka i izravne primjene čije se definicije razvijaju usporedno s razvojem i cjelokupnoga europskog prava i koji su mehanizmi njegova funkcioniranja, a ne ograničavajući čimbenik u ostvarenju ciljeva.

\section{Literatura}

Arnull, A. (1999). The European Union and its Court of Justice. Oxford, UK: Oxford University Press.

De Wiite, B. (1999). Direct effect, supremacy and the nature of the legal order. U C. de Burca (ed.) The Evolution of EU law (177-213). Oxford, UK: Oxford University Press.

Capeletti, M. (1989). The judicial process in comparative perspective. Oxford, UK: Clarendon Press.

Craig, P., \& de Burca, G. (2015). EU law: text, cases, and materials. Oxford, UK: Oxford University Press.

Craig, P. (2009). The legal effect of directives: policy, rules and exceptions. European Law Review, 34(3), 349-377. 
Edwards, C. (2016). Direct Effect and Direct Applicability: what do they really mean? Preuzeto s https://www.insidebrexitlaw.com/blog/direct-effect-and-direct-applicability-what-do-they-really-mean.

Everling, U. (1967). Europäisches Gemeinschaftsrecht und nationales Recht in der praktischen Rechtsanwendung. N. J. W, 67(20), 465-473.

Hartley, T. C. (2007). The foundations of European Community law. New York, SAD: Oxford University Press.

Hesselink, M. (2001). The new European legal culture. Denver, SAD: Kluver.

Kelsen, H. (1927). O granicama izmedu pravničke i sociološke metode. Beograd, Srbija: Nolit.

Kühn, Z. (2004). Worlds apart: Western and Central European judicial culture at the onset of the European enlargement. American Journal of Comparative Law, 52(3), 531-567, https://doi.org/10.2307/4144478

Kulcsár, K. (2001). Politics and law - making in Central-East- Europe. U Péteri Z. (ed.) Legal theory. comparative law. Studies in honour of Professor Imre Szabó. Budimpešta, Mađarska: Akadémiai Kiadó, https://doi.org/10.2307/840158

Mastroianni, R. (1999). On the distinction between vertical and horizontal direct effect of directives: what role for the principle of equality. European Public Law, 5(3), 417-435.

Mathijsen, P. S. R. F. (2013). Guide to European Community Law. London, UK, Sweet \& Maxwell.

Pescatore, P. (1972). Legal problems of an enlarged European community. London, UK: Stevens.

Prechal, S. (2005). Directives in EC law. Oxford, UK: Oxford University Press.

Rodin, S., \& Ćapeta, T. (2008). Učinci direktiva Europske unije u nacionalnom pravu. Zagreb, Hrvatska: Pravosudna akademija Zagreb.

Schutze, R. (2015). European Union law. Cambridge, UK: Cambridge University Press.

Shaw, J. (2000). The law of the European Union. London, UK: Palgrave Macmillan.

Winter, J. A. (1972). Direct applicability and direct effect two distinct and different concepts in community law. Common Market Law Review, 9(4), 425-438.

\section{Sudska praksa}

Predmet 26/62 NV Algemene Transport- en Expeditie Onderneming van Gend \& Loos v. Netherlands Inland Revenue Administration, (1963) ECR 1, https://doi. org/10.1093/he/9780191883743.003.0001

Predmet 39/72 Commission v. Italy, (1973) ECR 101

Predmet 34/73 Variola protiv Italian Finance Administration, (1973) ECR 981

Predmet 41/74 Yvonne van Duyn protiv Home Office, (1974) ECR 1337

Predmet 43/75 Defrenne protiv Sabena, (1976) ECR 455

Predmet 148/78 Publico Ministero protiv Tulio Ratti, (1979) ECR 1629 
Predmet 8/81 Becker protiv Finanzamt Münster-Innenstadt, (1982) ECR 53

Predmet C-271/91 Marshall v. Southbampton and South-West Hampshire Area bealth Authority, (1993) ECR I-4367

Predmet C-91/92 Dori protiv Recreb Srl, (1994) ECR I-3325

Predmet C-236/92 Comitato di Coordinamento per la Difesa della Cava protiv Regione Lambardia, (1994) ECH I-463

Predmet C-319/97 Kortas, (1999) ECR I-3143

Predmet C-365/97 Komisija protiv Italije, (1999) ECH I-7773

Predmet C-141/00 Ambulanter Pflegedienst Kügler GmbH protiv Finanzamt für Körperscaften, (2002) ECH I-6833

Predmeti C-37/06 i C-58/06 Viamex Agrar Handels GmbH i Zuchtvieh-Kontor GmbH (ZVK) protiv Hauptzollamt Hamburg-Jonas, (2008) ECR I-69

\section{Pravni propisi i policy dokumenti}

Priopćenje Komisije Vijeću i Europskom parlamentu »Poticanje rasta i kohezije u graničnim regijama EU-a«- $\operatorname{COM(2017)~} 534$ final, 20. 9. 2017.

Prijedlog uredbe Europskog parlamenta i Vijeća o mehanizmu za uklanjanje pravnih i administrativnih prepreka u prekograničnom kontekstu, 29. 5. 2018., Strasbourg, COM (2018), 373 final, 2018/0198 (COD)

Pročišćene verzije Ugovora o Europskoj uniji i Ugovora o funkcioniranju Europske unije, Ugovor o Europskoj uniji (pročišćena verzija), Ugovor o funkcioniranju Europske unije (pročišćena verzija), Protokoli, Prilozi Ugovoru o funkcioniranju Europske unije, Izjave priložene Završnom aktu Međuvladine konferencije na kojoj je donesen Ugovor iz Lisabona potpisan 13. prosinca 2007. Tablice ekvivalenata SL C 202, 7. 6. 2016., str. 1-388 (BG, ES, CS, DA, DE, ET, EL, EN, FR, GA, HR, IT, LV, LT, HU, MT, NL, PL, PT, RO, SK, SL, FI, SV), https://doi.org/10.25234/pv/8307

Uredba (EZ) br. 45/2001 Europskog parlamenta i Vijeća od 18. prosinca 2000. o zaštiti pojedinaca u vezi s obradom osobnih podataka u institucijama i tijelima Zajednice i o slobodnom kretanju takvih podataka, SL L 8, 12. 1. 2001., str. 1

Uredba (EZ) br. 1059/2003 Europskog parlamenta i Vijeća od 26. svibnja 2003. o uspostavi zajedničkog razvrstavanja prostornih jedinica za statistiku (NUTS), SL L 154, 21. 6. 2003., str. 1

Uredba (EU) br. 182/2011 Europskog parlamenta i Vijeća od 16. veljače 2011. o utvrđivanju pravila i općih načela u vezi s mehanizmima nadzora država članica nad izvršavanjem provedbenih ovlasti Komisije, SL L 55, 28. 2. 2011., str. 13

Ugovor o funkcioniranju Europske unije, SL C 202, 7. 6. 2016, str. 1-388

Treaty establishing the European Economic Community 11957E/TXT 


\section{CONCEPTS OF DIRECT APPLICABILITY AND DIRECT EFFECT IN THE EUROPEAN UNION LAW}

\section{Summary}

The paper analyses the concepts of direct applicability and direct effect, which were created and developed as the result of the practical usage of regulations and directives which are binding acts of secondary legislation. The author proves that in certain cases direct effect is acknowledged to directives, but denied to regulations; that in the case of directives, direct application is often the result of direct effect, and in the case of regulations, direct effect is in most cases the result of direct application; and that those concepts are sometimes and with respect to certain legal documents mutually conditioned, and sometimes not. Through the case by case method, the author goes on to claim that these are exceptions from the general rule and a consequence of the request for effectiveness of European law at the national level, as well as of the implementation of law. Nevertheless, those requirements and methods do not jeopardise the original basic legal rules, and although they derogate, they do not abolish the written basic legal rules. The requirements are necessary due to the development of European law and the accomplishment of its goals, and could be put at risk by the application of strict formalism. The European Court of Justice, as one of the creators of European law, strives not to abolish, but rather to call into question all interpretative rules that would represent or lead to formal legal thinking, and the application of rules that would in essence represent a kind of ontological consistency and reflect a grammatical obedience of the rules. However, it does not take into account the legal consequences. The concepts of direct effect and direct applicability should be regarded in such a spirit because their definitions are also in the process of parallel development with the development of European law as a whole, and taking into account that they are and should be the mechanisms of effective functioning of European law, rather than a restrictive factor in the way of the law acbieving its goal.

Keywords: direct applicability, direct effect, regulations, directives, European law 